\title{
Revealing the deeper structure of the end-glacial Pärvie fault system in northern Sweden by seismic reflection profiling
}

\author{
O. Ahmadi ${ }^{1}$, C. Juhlin ${ }^{1}$, M. Ask ${ }^{2}$, and B. Lund ${ }^{1}$ \\ ${ }^{1}$ Department of Earth Sciences, Uppsala University, Villavägen 16, 75236 Uppsala, Sweden \\ ${ }^{2}$ Department of Civil, Environmental and Natural Resources Engineering, Luleå University of \\ Technology, 97187 Luleå, Sweden \\ Correspondence to: O. Ahmadi (omid.ahmadi@geo.uu.se)
}

Received: 22 December 2014 - Published in Solid Earth Discuss.: 4 February 2015

Revised: 27 April 2015 - Accepted: 2 May 2015 - Published: 3 June 2015

\begin{abstract}
A new seismic reflection survey for imaging deeper levels of the end-glacial Pärvie fault system in northern Sweden was acquired in June 2014. The Pärvie fault system hosts the largest fault scarp so far documented in northern Scandinavia, both in terms of its length and calculated magnitude of the earthquake that generated it. Present-day microearthquakes occur along the length of the fault scarp on the eastern side of the scarp, in general agreement with an east-dipping main fault. In the central section of the fault system, where there is a number of subsidiary faults east of the main Pärvie scarp, it has been unclear how the earthquakes relate to the structures mapped at the surface. A seismic profile across the Pärvie fault system acquired in 2007, with a mechanical hammer as a source, showed a good correlation between the surface mapped faults and moderate to steeply dipping reflections. The most pronounced reflectors could be mapped to about $3 \mathrm{~km}$ depth. In the new seismic survey, for deeper penetration an explosive source with a maximum charge size of $8.34 \mathrm{~kg}$ in $20 \mathrm{~m}$ deep shot holes was used. Reflectors can now be traced to deeper levels with the main $65^{\circ}$ east-dipping fault interpreted as a weakly reflective structure. As in the previous profile, there is a strongly reflective $60^{\circ}$ west-dipping structure present to the east of the main fault that can now be mapped to about $8 \mathrm{~km}$ depth. Extrapolations of the main and subsidiary faults converge at a depth of about $11.5 \mathrm{~km}$, where current earthquake activity is concentrated, suggesting their intersection has created favorable conditions for seismic stress release. Based on the present and previous seismic reflection data, we propose potential locations for future boreholes for scientific drilling into the fault system. These boreholes will provide a better understanding of
\end{abstract}

the reflective nature of the fault structures and stress fields along the faults at depth.

\section{Introduction}

During the last glaciation the ice that covered much of northern Europe, with thickness in excess of $3 \mathrm{~km}$, gave rise to dynamic changes in the stress field of the Fennoscandian Shield (Pascal et al., 2010). Towards the end of the glaciation, the ice melted rapidly in northern Fennoscandia and the effective stress field changed accordingly, generating major faulting (Lagerbäck, 1978) with associated large earthquakes (M7-8.2; e.g., Muir-Wood, 1988; Arvidsson, 1996; Lindblom et al., 2015). The resulting fault scarps have been alternatively termed end-glacial scarps, post-glacial fault scarps or glacially induced fault scarps; we use the first term in this paper as it is appropriate for the Pärvie fault.

Important questions concerning the end-glacial faults are as follows: (i) what is the geometry of the faults at depth and their extent? (ii) What was the stress field that caused these ruptures during the last deglaciation? (iii) What is the stress field at depth that is generating the current earthquake activity along the faults. Knowledge of the fault geometry is important for understanding the stress required to activate the faults during the last deglaciation and also for predictions of potential future earthquakes along these faults (e.g., Lund et al., 2009).

End-glacial fault scarps are present at a minimum of 14 known locations in Finland, Norway and Sweden and are up to $155 \mathrm{~km}$ in length, with a maximum surface displacement 
a)

b)

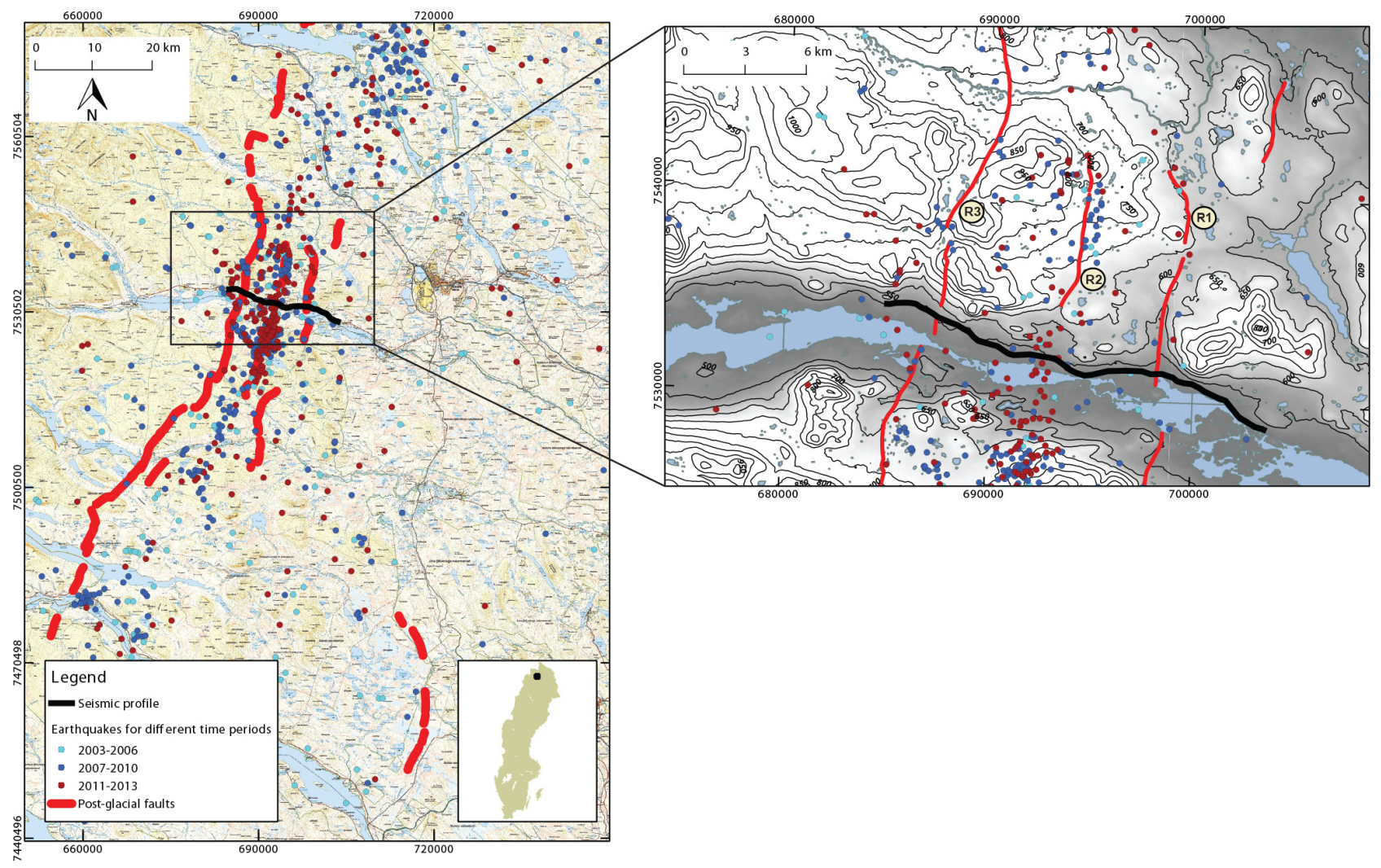

Figure 1. Location of the seismic profile over the Pärvie fault system in northern Sweden. Earthquakes are shown for three different time periods (after Lindblom et al., 2015). Inset shows the location of the Pärvie area in northern Sweden. (b) The end-glacial Pärvie faults overlaid on a topographic map. ${ }^{\circledR}$ Lantmäteriet I2014/00601.

of up to $30 \mathrm{~m}$ (Kuivamäki et al., 1998; Olesen et al., 2004; Lagerbäck and Sundh, 2008). They generally strike in the NE-SW direction, dip toward the southeast and show reverse faulting motion. The longest of the scarps, located in northern Sweden, belongs to the Pärvie fault system and has been the focus of recent geophysical studies, including reflection and hydroacoustic seismic surveying (see Fig. 1) (Juhlin et al., 2010; Vogel et al., 2013), a temporary seismic network (Lindblom et al., 2015) and remote sensing (Mantovani and Scherneck, 2013).

To investigate an end-glacial fault at depth and help unravel the stress history of northern Fennoscandia, the Drilling into Active Faults in Northern Europe (DAFNE) project has been initiated (Kukkonen et al., 2010, 2011). Deep research boreholes to depths of $2-3 \mathrm{~km}$ are planned in order to better understand the present-day stress field and the seismicity associated with the faults, as well as studying the geology, fluids, gases and microbes in the end-glacial faults. The DAFNE project is part of the Swedish Scientific Drilling Program (www.ssdp.se) and the International Continental Scientific Drilling Program (www.icdp-online.org). The reflection seismic survey presented in Juhlin et al. (2010) was a first step toward optimally positioning a deep borehole in the fault system.

A recent reflection seismic survey (acquired in 2007) across the Pärvie fault system west of the city of Kiruna showed that the faults comprising the system have moderate to steep dips and planar geometries down to at least 2$3 \mathrm{~km}$ depth (Juhlin et al., 2010). Similar geometries were found for faults belonging to the Burträsk fault system further to the southeast (Juhlin and Lund, 2011). The more sub-horizontal reflections from the Pärvie area were interpreted as possibly originating from deeper-lying greenstones or gabbroic bodies. The main east-dipping Pärvie fault was not very reflective in contrast to a parallel west-dipping subsidiary fault within the system. Juhlin et al. (2010) suggested that the Pärvie fault system could represent a flower structure and concluded that it is unlikely that the main fault becomes listric above $6 \mathrm{~km}$ depth. Mapping of brittle deformation structures on outcrops in the area of the main fault also indicates relatively steep dips in the near surface (Riad, 1990).

In this paper, we present results from a new seismic survey across the Pärvie fault system (Fig. 1), which was acquired in June 2014 using a more powerful dynamite source, but with 
Table 1. Seismic acquisition parameters used during the seismic recording.

\begin{tabular}{ll}
\hline Profile length & $22 \mathrm{~km}$ \\
Seismic source & Explosive $8.34 \mathrm{~kg}$ shot hole $^{-1}$ \\
Geophone & $10 \mathrm{~Hz}$ \\
Receiver spacing & $25 \mathrm{~m}$ \\
Nominal shot spacing & $400 \mathrm{~m}$ \\
Sampling rate & $1 \mathrm{~ms}$ \\
Number of shots & 100 \\
Percentage of shots with & $92 \%$ \\
full charge & \\
Recording length & $25 \mathrm{~s}$ \\
Active channels & $300-390$ \\
Recording date & June 2014 \\
\hline
\end{tabular}

a sparser spacing between the source points and with longer offsets. The Juhlin et al. (2010) survey used an industrial hydraulic hammer as a seismic source and an asymmetric splitspread recording geometry. Using several kilograms of explosives in deep shot holes will generally generate seismic signals that penetrate the earth deeper than a surface-based operated hammer. Therefore, it was expected that the new survey would verify the geometry of the main Pärvie fault and allow mapping of the subsidiary faults to deeper levels in the crust, but with a lower-resolution image of the uppermost few kilometers. This was indeed the case, and together with re-migrated sections of the previous data with the velocity model obtained from Lindblom et al. (2015) we show how the fault system can be mapped to greater depth and how the obtained image can be correlated with the earthquakes occurring in the area.

\section{Tectonics and seismicity of the area}

The Pärvie fault is located in the intraplate Baltic Shield, mostly in Paleoproterozoic rock on the boundary to the Archean terrain of northernmost Sweden. It runs parallel with, and only some $10-50 \mathrm{~km}$ away from, the Ordovician Caledonian mountain front. The establishment of permanent seismic stations in northern Sweden in 2003-2004, as part of the Swedish National Seismic Network (Bödvarsson and Lund, 2003), showed that the Pärvie fault, and the other endglacial faults in northernmost Sweden, are still seismically active. In fact, $70 \%$ of the earthquakes recorded north of $66^{\circ} \mathrm{N}$ since 2003 are located within $30 \mathrm{~km}$ to the southeast and $10 \mathrm{~km}$ to the northwest of an end-glacial fault; this is consistent with the observed reverse faulting, dip to the southeast, character of the faults (Lindblom et al., 2015). Between 2007 and 2010 a temporary network of seismic stations was operated along the Pärvie fault, bringing the number of stations in the vicinity of the fault to 15 . Although still sparse for a $155 \mathrm{~km}$ long fault, the temporary network significantly improved the detection threshold and location accuracy along the fault. Lindblom et al. (2015) analyzed the earthquakes recorded along the Pärvie fault between 2003 and 2013. The epicentral locations (Fig. 1) show that the earthquakes occur all along the mapped fault scarp, mostly on the eastern side of the fault in accordance with an east-dipping reverse fault. In the southern section, and even more pronounced in the northern section (not shown in Fig. 1), the epicentral locations are at some distance from the fault scarp, whereas in the central section of the fault the earthquakes occur closer to the main fault, seemingly bounded by the main fault and a west-dipping subsidiary fault. Cross sections in Lindblom et al. (2015) show that events generally tend to occur deeper to the east, although there are still too few events to see a well-defined fault zone dipping to the east, if that is the case. The dip of the zone of earthquakes is somewhere between 30 and $60^{\circ}$, more shallow to the north and south, and steeper in the center, as indicated by the distance between earthquakes and the fault scarp in Fig. 1. Events are recorded down to $35 \mathrm{~km}$ depth. Assuming that the currently active zone of earthquakes outlines the fault that ruptured 10000 years ago, that event is estimated to have had a magnitude of $8.0 \pm 0.4$ (Lindblom et al., 2015). Since 2003, no event larger than magnitude 2.9 has been recorded along the fault, and the largest known modern event was a magnitude 3.7 in 1967.

At four locations along the main Pärvie fault, recent investigations on outcrop scale of the kinematics of brittle deformation structures identify four paleostress fields (Bäckström et al., 2013): three of the paleostress fields are also found in other major shear zones in the area (e.g., Edfelt et al., 2006), whereas the fourth, and most recent field, seems to be unique for the Pärvie fault. This structure indicates a reverse stress field with a strike-slip component (A. Bäckström, personal communication, 2014).

On the larger scale the stress field in Fennoscandia is suggested to be dominated by ridge-push (e.g., Gregersen, 1992; Lund and Zoback, 1999; Slunga, 1991) with contributions from glacial isostatic stress redistribution, sediment loading, topography and erosion (Bungum and Lindholm, 1997). In the north, the stress field is poorly known at depths below $500 \mathrm{~m}$. The World Stress Map has no other stress indicators than single focal mechanisms below $500 \mathrm{~m}$ (there are only six data points onshore north of $65^{\circ} \mathrm{N}$ ), and they show both reverse and normal faulting conditions, with $P$ axes mostly in a general E-W direction, albeit with large variations (Heidbach et al., 2008). Preliminary investigations of the focal mechanisms obtained with the temporary seismic network on the Pärvie fault also show a large variation in focal mechanisms; most are, however, strike-slip to reverse, with a general NW-SE direction of the $P$ axes (Lindblom and Lund, 2011), consistent with a ridge-push-derived stress field. 
Table 2. Seismic data processing steps.

\begin{tabular}{|c|c|c|}
\hline 1. & Reading SEGD files and sorting the data & \\
\hline 2. & Geometry setting & \\
\hline 3. & Picking first arrivals & \\
\hline 4. & Inner trace muting & \\
\hline 5. & Refraction static correction & \\
\hline 6. & Spectral balancing & SPEQ 10-20-100-150 Hz \\
\hline 7. & Spherical divergence correction & \\
\hline 8. & Band pass filtering & $10-20-100-150 \mathrm{~Hz}$ \\
\hline 9. & Reflection residual correction & \\
\hline 10. & FXDECON & 7-traces window \\
\hline 11. & Time-variant filtering & $\begin{array}{l}0-650 \mathrm{~ms} \text { : high pass } 3-70 \mathrm{~Hz} 655-5000 \mathrm{~ms}: \\
\text { Band pass } 15-25-90-120\end{array}$ \\
\hline 12. & Velocity analysis & \\
\hline 13. & NMO correction & Constant velocity $13000 \mathrm{~m} \mathrm{~s}^{-1}$ \\
\hline 14. & Velocity analysis & \\
\hline 15. & First arrival and ground roll muting & \\
\hline 16. & Stacking & \\
\hline 17. & FXDECON & 7-traces window \\
\hline 18. & Band pass filtering & $15-25-90-120 \mathrm{~Hz}$ \\
\hline 19. & Migration & \\
\hline
\end{tabular}

\section{Seismic acquisition}

Table 1 shows the acquisition parameters which were used in the seismic survey. The seismic profile was laid out almost in the same location as the previous survey (Juhlin et al., 2010) (see Fig. 1). In order to resolve the geometry of the Pärvie fault system deeper than the previous studies (Juhlin et al., 2010), the new seismic survey in the area was acquired in June 2014 using an explosive source. A number of studies in Sweden indicate that $10 \mathrm{~kg}$ of explosives is sufficient to image the crust down to Moho depths (Juhojuntti and Juhlin, 1998; Juhojuntti et al., 2001; Juhlin et al., 2002). Therefore, we used dynamite as a seismic source with a maximum charge size of $8.34 \mathrm{~kg}$ in $20 \mathrm{~m}$ deep shot holes. In about $8 \%$ of the shots, because of logistical problems, a minimum charge size of $2.78 \mathrm{~kg}$ of the explosive was used. The acquisition was carried out with an end-on array. To obtain good coverage for seismic imaging, each shot was repeated three times for different spreads along the profile, reusing shot holes on the repeat shots. Nominal shot spacing was $400 \mathrm{~m}$, but 15 shots had to be skipped because the shot holes had collapsed after previous explosions in them. Receiver spacing was $25 \mathrm{~m}$, with single $10 \mathrm{~Hz}$ geophones deployed during the recording. The data were acquired with a sampling rate of $1 \mathrm{~ms}$, and total recording length was $25 \mathrm{~s}$, allowing us to investigate deep structures. Signal-to-noise ratios are high in the data, but the shot and receiver spacing used in the acquisition resulted in a sparse data set (see midpoint distribution in Fig. 2).

\section{Seismic data processing}

Field SEGD files were converted to SEGY format and then sorted by source location along the profile. The geometry of the survey was configured and a straight CDP line was chosen for processing (Fig. 2). Table 2 shows the processing steps which were applied to this data set. An inner trace mute was applied to remove bad traces, and refraction static corrections were performed to improve the coherency of the gathers. First arrivals became better aligned after applying the refraction static correction (Fig. 3a and b). In an attempt to balance seismic traces and to attenuate ringing signals, a spectral balancing filter $(10-20-100-150 \mathrm{~Hz})$ was applied. The main sources for noise in the data were traffic on the road close to the profile and natural features like drainages. Filter tests showed that no improvement was obtained in the images by retaining lower frequencies. Spherical divergence corrections and band pass filtering $(10-20-100-150 \mathrm{~Hz})$ were also performed in the pre-stack processing. Residual static corrections were calculated in a further attempt to increase the coherency of the reflections, but without significant improvement (less than $0.5 \mathrm{~ms}$ ). An FX-decon filter with a window length of seven traces was used to enhance linear reflectivity of the reflections in the pre-stack domain. Figure $4 \mathrm{a}$ and $\mathrm{b}$ show a shot gather before and after applying the FX-decon filter; a linear reflection is enhanced which intersects the surface at about receiver peg 105. Time-variant filtering and velocity analysis were also carried out before stacking. An extensive velocity analysis was performed, and finally a normal move-out (NMO) correction with a high constant velocity of $13000 \mathrm{~m} \mathrm{~s}^{-1}$ resulted in the best image of the dipping structures in the subsurface (Fig. 5). Given that NMO veloc- 


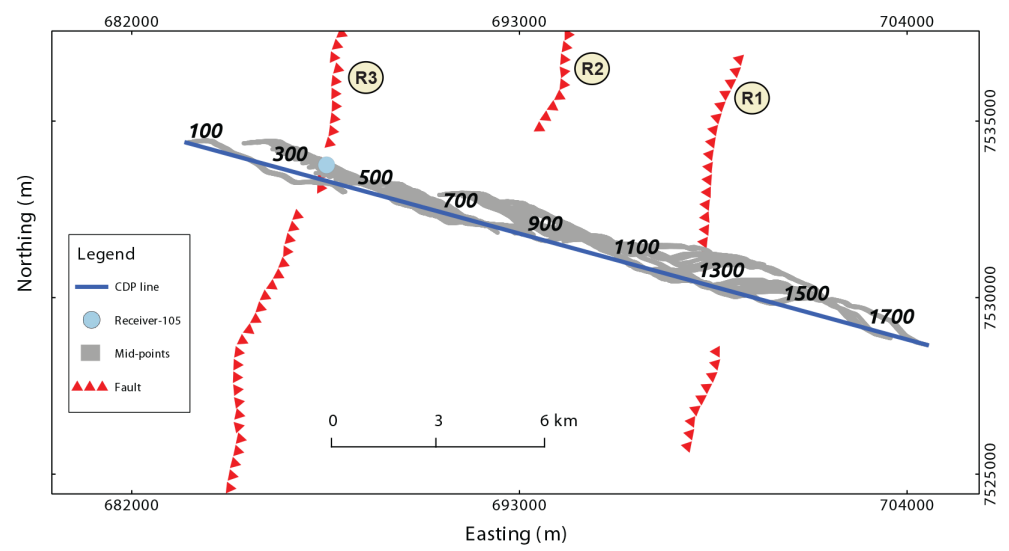

Figure 2. The seismic profile location across the Pärvie fault system. The midpoint distribution shows the sparsity of the data. Location where a weak reflection was recorded in a few shot gathers, corresponding to the main fault and receiver 105 (see Fig. 4), is marked on the map.

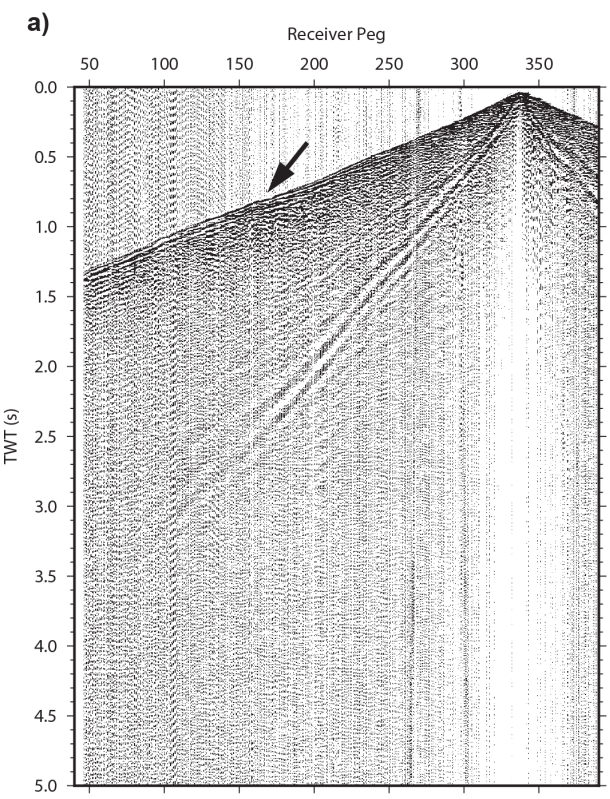

b)

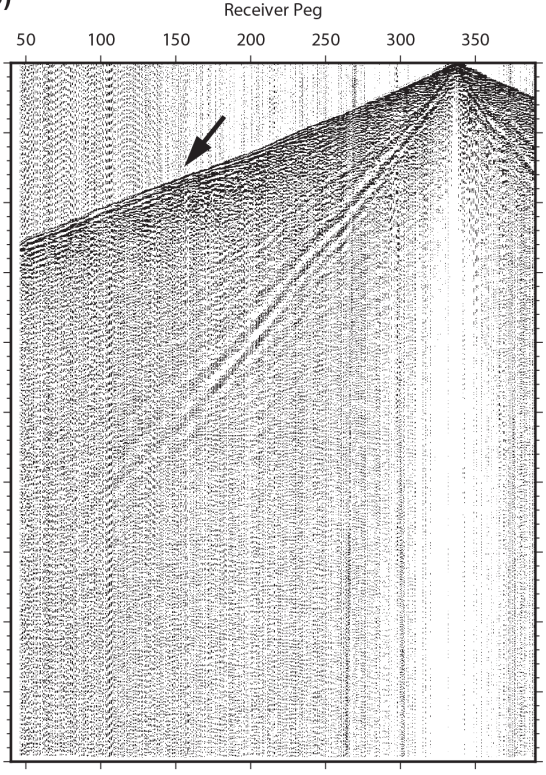

Figure 3. A shot gather (a) before refraction static correction (step 5; see Table 2) and (b) after the correction. The black arrow shows first arrivals which are improved and aligned after static correction.

ity should scale by the inverse of the cosine of the dip, the $13000 \mathrm{~m} \mathrm{~s}^{-1}$ choice is consistent for reflections dipping at $60^{\circ}$. Attempts to perform dip move-out (DMO) corrections were not successful, most likely due to the sparsity of the data and low fold in the offset gathers. To enhance the reflections on the stacked section, a post-stack FX-decon filter, with a window length of seven traces, and a band-pass filter $(15-25-90-120 \mathrm{~Hz})$ were applied. Finally, the reflections were migrated to their approximate true locations using the finite-difference migration method and depth-converted using a variable velocity extracted from 3-D local earthquake tomography (Lindblom et al., 2015) (see Fig. 6). Furthermore, to have more constraints on resolving the geometry of the faults, we re-migrated two portions of the Juhlin et al. (2010) data using the gradient velocity model from the 3-D local earthquake tomography of Lindblom et al. (2015) (Fig.7). The seismic sections were then depth-converted with the same velocity model.

\section{Interpretation}

The conventional processing results show a strong westdipping reflection on the stacked section, which can be extrapolated to the surface to about CDP 1300 (reflection R1 in Fig. 5, using the same nomenclature for the faults as in Juhlin et al., 2010). This reflection appears to be relatively 
a)

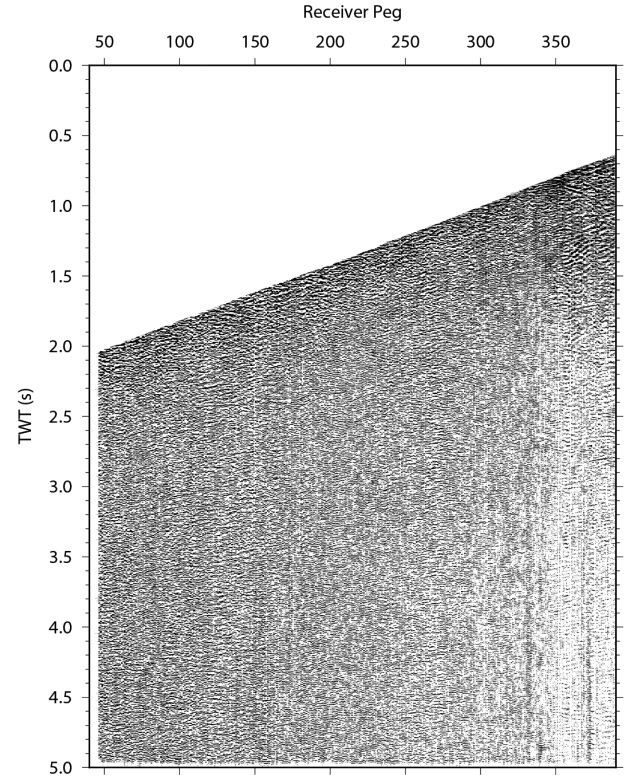

b)

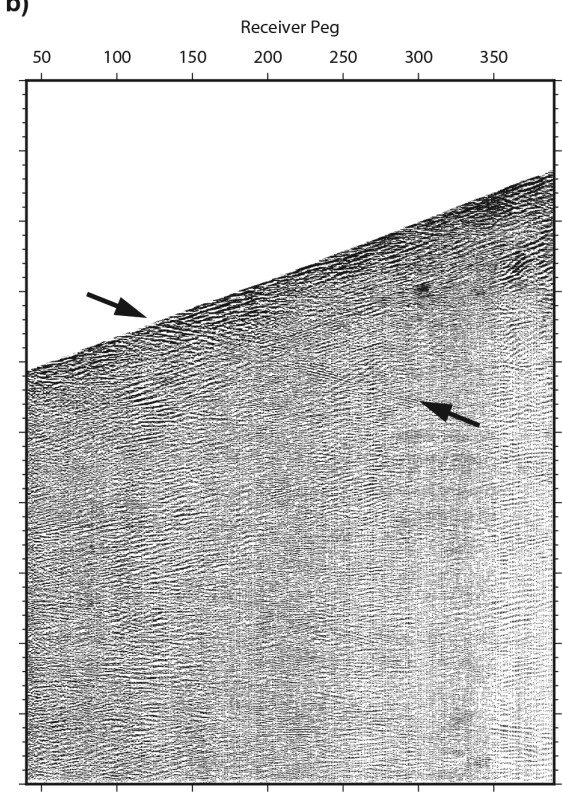

Figure 4. Application of FX-decon in pre-stack processing (a) before and (b) after FX-decon. The arrows show an enhanced reflection which is exposed at about receiver peg 105 at the surface and corresponds to the main east-dipping Pärvie fault (see the location of the receiver in Fig. 2).

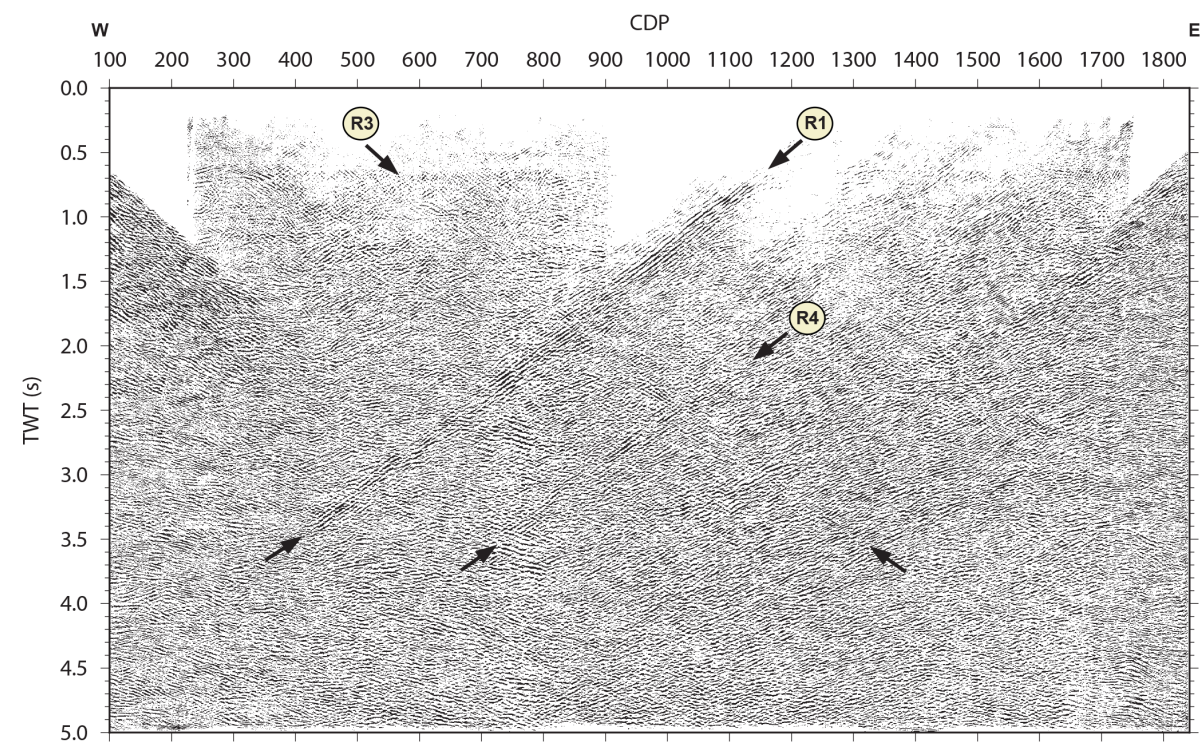

Figure 5. The NMO stacked section. Reflections R1 and R3 (shown by the arrows) correspond to the subsidiary west-dipping fault and the main Pärvie fault, respectively. Reflection R4 most likely is another west-dipping fault in the subsurface.

planar and can be traced down to a depth of about $8 \mathrm{~km}$ on the migrated and depth-converted section (Fig. 6). Juhlin et al. (2010) linked this strongly reflective structure to a westdipping subsidiary fault in the Pärvie fault system (Lagerbäck and Sundh, 2008). Although weak, a trace of the main Pärvie fault was recorded and enhanced in the pre-stack and the post-stack seismic processing (Figs. 3 and 4). Figure 3 shows a shot gather in which a linear reflection has been en- hanced and appears to intersect the surface at receiver peg 105, close to the location of the main Pärvie fault (Fig. 2). Based on the previous geophysical and geological studies, the main fault dips to the southeast (Juhlin et al., 2010; Lagerbäck and Sundh, 2008) (see Fig. 7a), which is also consistent with the weak reflection marked by R3 in Figs. 5 and 6. In addition, another planar west-dipping reflection is observed further east on the profile and can be traced from $3.5 \mathrm{~km}$ down 


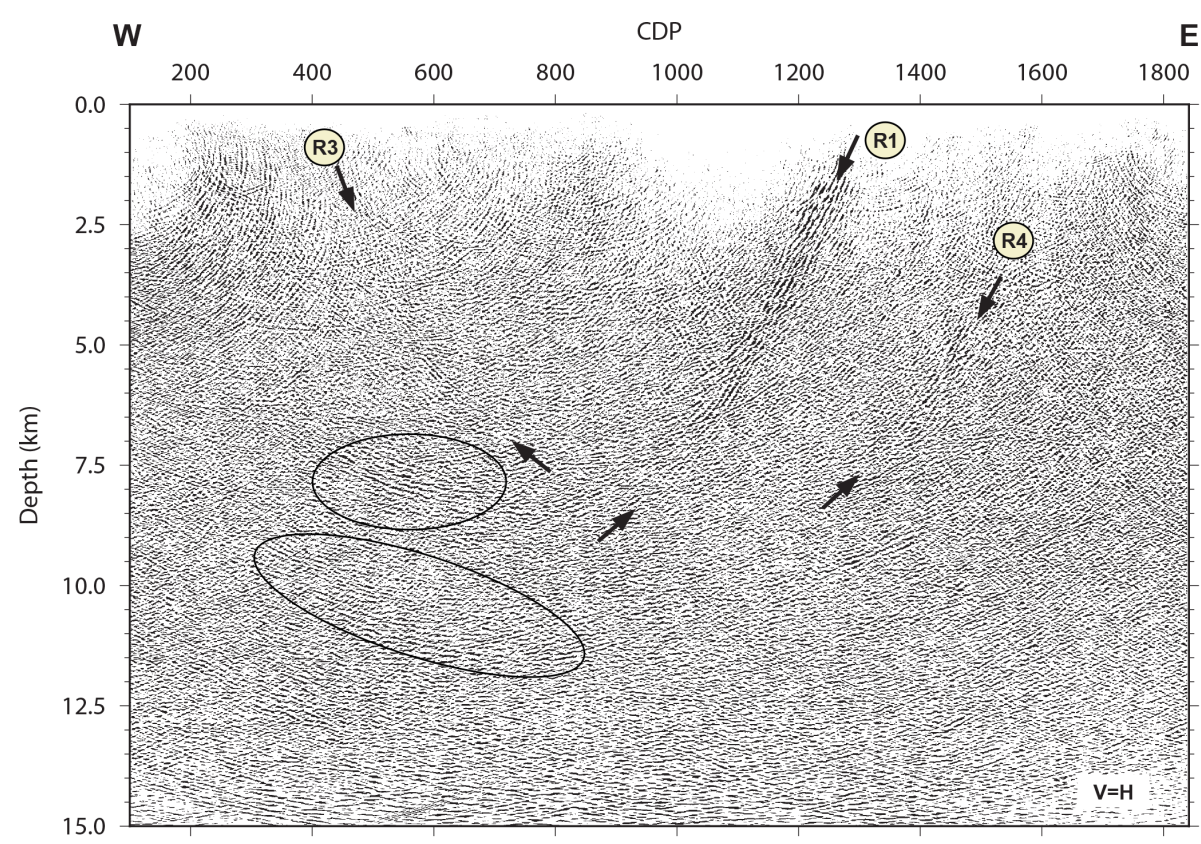

Figure 6. The migrated section. The reflections (shown by the arrows) were migrated to their true locations using the velocity model provided by Lindblom et al. (2015).

a)

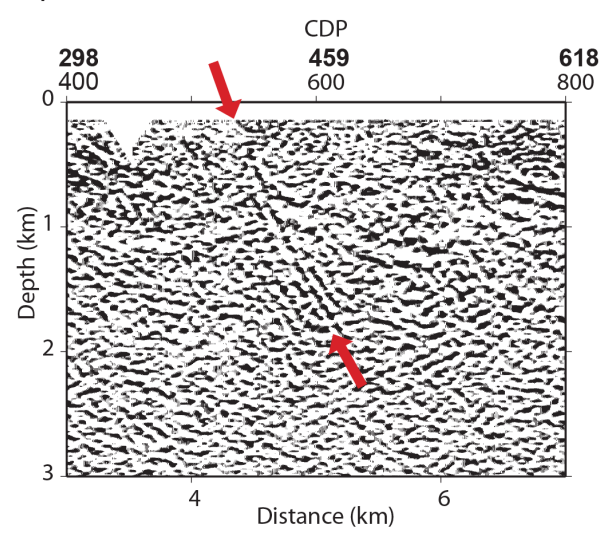

b)

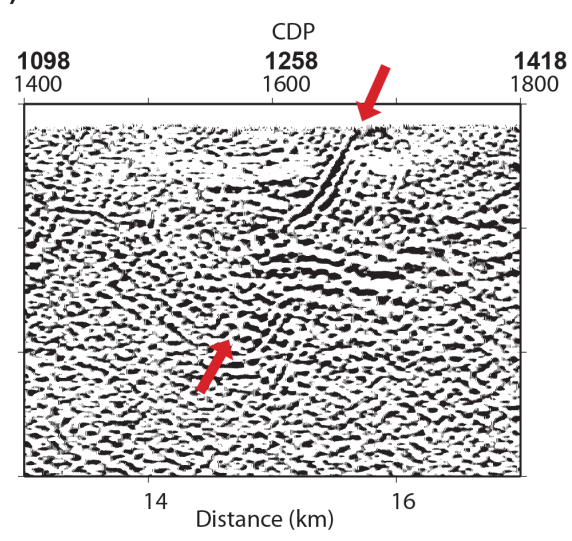

Figure 7. The re-migrated sections of the previous seismic survey (Juhlin et al., 2010) with the velocity model provided by Lindblom et al. (2015). (a) The image of the main Pärvie fault (R3); (b) the image of the west-dipping subsidiary fault (R1). The images show that the R1 and R3 faults (shown by the red arrows) dip at about 60 and $65^{\circ}$ to the west and the east, respectively. CDP numbers from the new explosive survey are shown in bold. The vertical exaggeration is $1 \times$.

to $7 \mathrm{~km}$ depth (reflection R4 in Fig. 6). A reflection corresponding to this feature was also observed on the previous profile (Juhlin et al., 2010) but could only be mapped down to $2-3 \mathrm{~km}$ depth. It was interpreted as a previously unknown end-glacial fault belonging to the Pärvie fault system, which subsequently has been identified in new lidar data (Mikko et al., 2015). Based on the re-migrated sections of the previous survey shown in Fig. 7, the true dips for reflections R1 and R3 are interpreted to be 60 and $65^{\circ}$, respectively. A dip for reflection R4 was not calculated but is on the same order as that for reflection R1, assuming that the structure generating it is close to perpendicular to the profile.

In addition to the more steeply dipping reflections, some more sub-horizontal reflections are observed at depths of about $7.5 \mathrm{~km}$ or deeper (see the two ellipses in Fig. 6). Juhlin et al. (2010) suggested, based on seismic forward modeling, that the shallower sub-horizontal reflections on the previous profile could correspond to the top of mafic or ultramafic intrusions at depth. It is also likely that these deep subhorizontal reflections originate from mafic units at depth. 


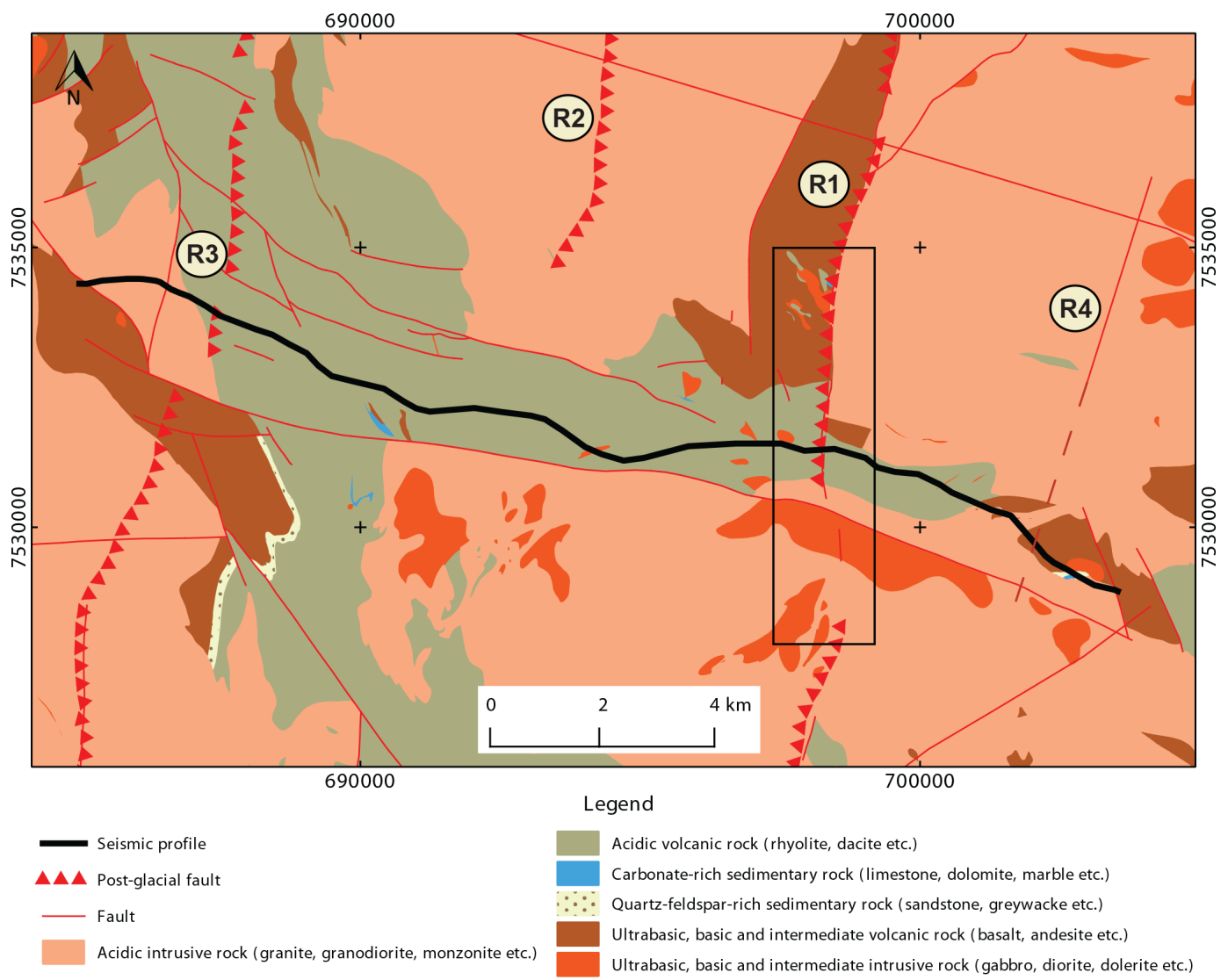

Figure 8. The bedrock geological map of the area based on Geological Survey of Sweden (SGU) database. The rectangle shows where the ultramafic rocks are exposed around the strongly reflective fault R1 (see Fig. 5).

\subsection{Reflectivity of the faults}

The main Pärvie fault (reflection R3) and the west-dipping reflection R1 in Figs. 5 and 6 have different reflectivity characteristics. The main fault is a weakly reflective structure, while the subsidiary west-dipping fault indicates the presence of a strong impedance contrast. Regardless of the NMO velocity used in the correction this difference is observed. Therefore, the difference cannot be attributed to processing. Possible explanations for this difference include secondary mineralization; varying fluid content; and pressure, anisotropy and thickness of fracture zones (Haney et al., 2007; Haugen and Schoenberg, 2000; Jones and Nur, 1982). Mineralization along a fault may increase the velocity of the rocks within the fault zone and therefore change the seismic impedance (Jones and Nur, 1982). What type of mineralization is present depends on the surrounding rocks and the alteration processes which have occurred along the fault. Figure 8 shows the rock type distribution near the Pärvie fault system. Ultramafic intrusive rocks outcrop in different locations. These rocks are mostly exposed near the west-dipping fault (reflection R1) at the surface. In the area marked by the rectangle in Fig. 8 these ultramafic bodies are clearly bounded by the fault. This suggests that the west-dipping fault cuts these ultramafic intrusions and therefore that the fault zone has a potential to be filled by secondary minerals such as silicates, phyllosilicates or calcium that crystallized during or after the post-glacial deformation. The presence of water in the fault can also speed up this process, while the water itself can decrease seismic impedance along the fault (Jones and Nur, 1982).

Jones and Nur (1982) suggest another possibility for strong reflectivity along faults: the existence of high fluid pressure. In order to have a high pore (fluid) pressure along a fault, it is necessary to have a confined structure also along it. This can be accomplished by mylonitic rocks along faults having a tight fabric which eliminates void (pore) spaces and allows the faults to be impermeable structures (Jones and Nur, 1982). In addition, the direction of anisotropy along the faults should be considered to explain their reflectivity. This factor is more important where phyllosilicate minerals such as mica and biotite are present as secondary minerals along the faults. Velocities of seismic waves vary if the waves travel parallel to foliation of the phyllosilicates or perpendicular to them (Jones and Nur, 1982). 


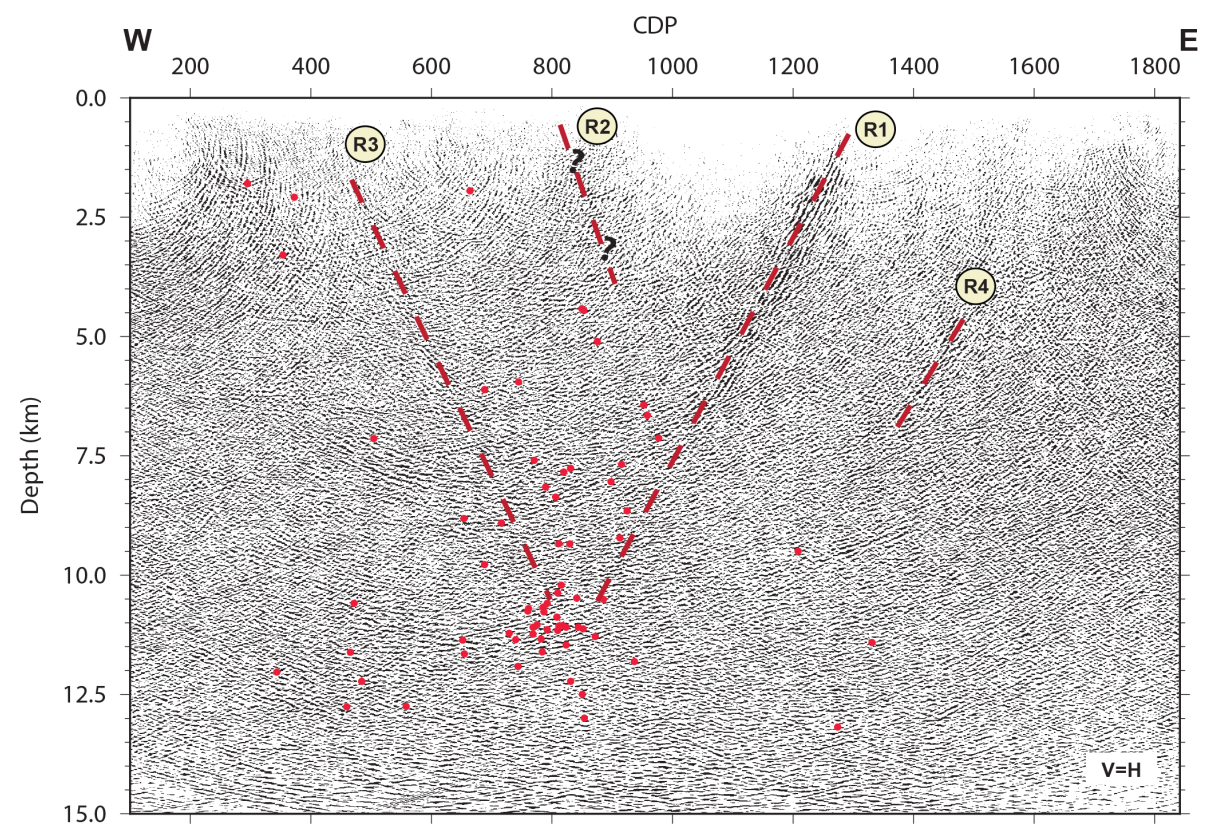

Figure 9. Cross section of the earthquakes overlaid on the interpreted migrated section. Red dashed lines depict the interpreted faults. Fault R2 was not imaged in the new seismic survey. All events within a maximum offset of $10 \mathrm{~km}$ perpendicular to the seismic profile to the north and south are projected onto the CDP plane. A dense cluster of seismic activity is located at a depth of about $11.5 \mathrm{~km}$. The listric appearance of the R1 and R3 reflections at depth is most likely due to the migration process and not a feature of the faults. We have interpreted the faults to be planar based on the unmigrated sections.

The thickness of the west-dipping reflection which corresponds to the west-dipping fault is on the order of $500-800 \mathrm{~m}$, while the R3 reflection is much thinner (Figs. 5 and 6). The greater apparent thickness may be the result of increased fracturing in the subsurface due to displacements along an active fault. The thicker the fractured zone, the more seismic reflectivity can be observed. The thickness of the fault R1 appears to decrease with the depth (Fig. 6), suggesting that the fracture zone of the fault is larger near to the surface.

The difference between the thicknesses of the fracture zones along the faults is a possible explanation for the difference between the reflectivity of the faults. However, if secondary mineralization has occurred along the faults, then the fault R1 has more capacity to host the secondary minerals than the thinner R3 fault.

\section{Discussion}

The three steeply dipping faults are imaged down to about $7.5 \mathrm{~km}$ in the new data set, while Juhlin et al. (2010) showed four faults in their seismic images down to about $2-3 \mathrm{~km}$. The R2 fault from Juhlin et al. (2010) has not been imaged in our seismic processing. The sparsity and low fold of the data set did not allow clear imaging of the R2 fault (Fig. 9). If the R1 and R3 faults are extrapolated with their respective dips in Fig. 7, these faults converge at a depth of about
$11.5 \mathrm{~km}$ (Fig. 9). The location of earthquakes in the area have been projected onto the migrated and depth-converted seismic section (red dots in Fig. 9). Only well-constrained microearthquakes within an area of $400 \mathrm{~km}^{2}$, and with a maximum offset of $10 \mathrm{~km}$ perpendicular to the seismic profile, are projected onto the migration plane. A denser cluster of seismic events is located below the imaged faults, suggesting that the intersection at $11.5 \mathrm{~km}$ depth of the main Pärvie fault and the west-dipping R1 fault is the source of the seismic activity in the area. Seismicity at intersections of faults has been observed in other locations around the world (e.g., Sausse et al., 2010). The geometry of the R1 and R3 faults is uncertain below this depth. The main fault (R3) may continue at a similar dip to the east, as indicated more clearly by seismicity on the northern and southern segments of the fault (Lindblom et al., 2015), or it may become listric at deeper levels. As indicated in Fig. 10, the earthquake activity below $13-14 \mathrm{~km}$ depth is sparse in the vicinity of the reflection profile and the continuation of the fault is poorly constrained by the earthquakes.

Another scenario is the existence of a flower structure (Juhlin et al., 2010) in which the R1 and R3 faults converge to a master fault at depths of about 11-12 km. We note, however, that the deeper part of such a flower structure would be virtually aseismic, as there are no recorded earthquakes directly below the cluster in Fig. 10. As seen in Fig. 10, there are deeper seismic events east of the study area, in better 


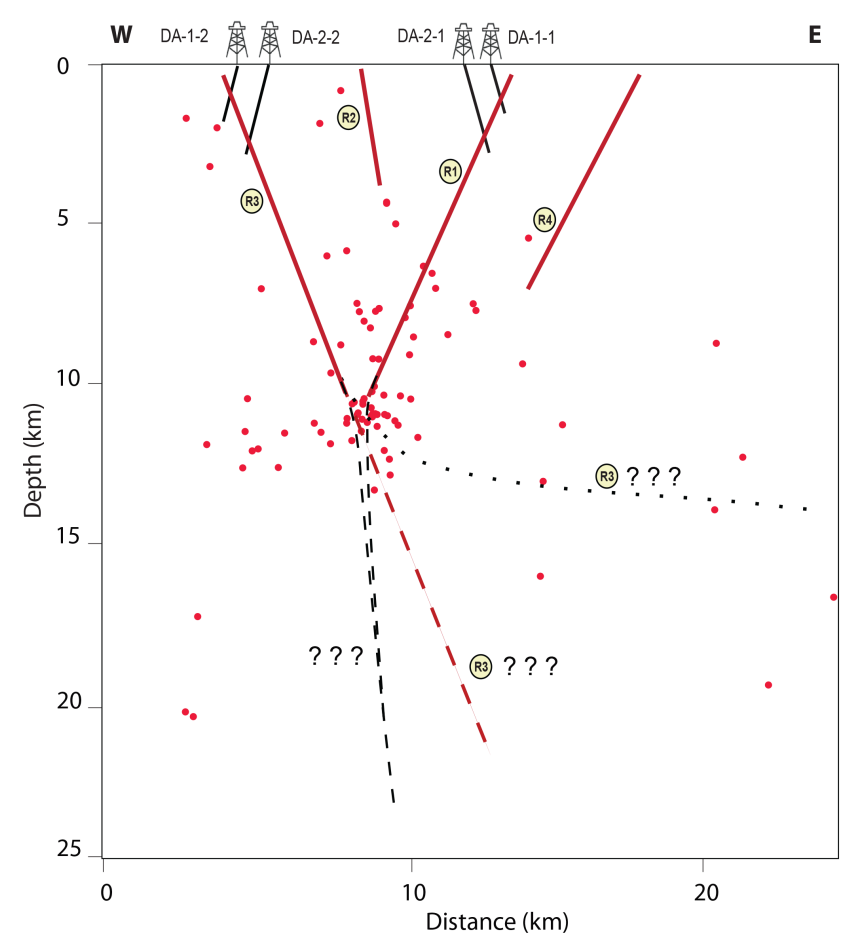

Figure 10. A simplified model of the Pärvie fault system. A larger area compared with Fig. 9 with projected earthquakes (red dots) and the location of some possible boreholes is shown. Below $8 \mathrm{~km}$ depth, the main fault (R3) may continue at a similar dip (shown by the red dashed line), become listric (marked by the dotted line) or form the lower part of a flower structure (marked by the black dashed lines). During the first phase of the drilling project (DAFNE), boreholes DA-1-1 and DA-1-2 will penetrate the R1 and R3 faults at about $1 \mathrm{~km}$ depth, respectively. Based on the result of the first phase, one deep borehole (either DA-2-1 or DA-2-2) will be chosen to drill into R1 or R3 at a depth of about $2.5 \mathrm{~km}$.

agreement with a listric or generally east-dipping fault structure. In addition, the seismicity in the northern and southern sections of the fault does not support a fault-wide flower structure but rather an east-dipping fault zone (Lindblom et al., 2015).

This paper provides critical site survey information for the DAFNE ICDP drilling proposal. The difference in reflectivity for the reflectors R1 and R3 has strongly influenced the drilling plan. Originally it was planned to drill a series of boreholes into the main fault at ever-increasing depth down to $2.5 \mathrm{~km}$ (Fig. 10). Drilling is now planned to be executed in two phases, with the first phase consisting of drilling two $1 \mathrm{~km}$ deep boreholes into the reflectors R1 and R3 and then conducting borehole logging, in situ testing, installing borehole seismometers for monitoring seismicity and other processes along the faults. Other sensors to monitor variation of various parameters such as pore pressure, temperature and water geochemistry over time will also be installed. Based on the results from the first two boreholes, a deeper borehole to $2.5 \mathrm{~km}$ will be drilled into one of the faults (Fig. 10). Borehole logging, in situ testing and monitoring will be conducted in the deeper borehole as well. The time-series data are anticipated to yield a better understanding of the dynamics of the Pärvie fault system, as well as allow for comparisons with other fault-zone drilling projects worldwide. Combined reprocessing of the two surveys with 3-D swath imaging (e.g., Malehmir et al., 2009) may also help in determining the optimum location for the deep borehole in phase two.

\section{Conclusions}

The Pärvie fault system was activated during the last glacial retreat in northern Sweden. In order to better understand the geometry of the faults, we carried out a deep seismic survey using dynamite as an explosive source. Although the acquisition parameters resulted in a sparse data set, the quality of the data in terms of signal-to-noise ratio was good, due to the use of an explosive source. The data were processed following a conventional CDP processing method down to $5 \mathrm{~s}$ along a straight line. Three reflections, corresponding to three steeply dipping faults and some sub-horizontal reflections were imaged. The reflections were migrated to their approximate true locations using the finite-difference migration method with a velocity model extracted from the 3-D local seismic network tomography and were traced down to a depth of about $7.5 \mathrm{~km}$. Although weak, the main Pärvie fault is imaged dipping at approximately $65^{\circ}$ to the east. A subsidiary, $60^{\circ}$ westdipping fault is significantly more reflective. We interpret the subsidiary west-dipping fault as consisting of a thicker fracture zone than the main Pärvie fault, explaining the difference in the reflectivity of the faults. Alternatively, the faults can have similar thickness, but the impedance contrast to the host rock may be greater for R1 than R3. Recent earthquakes cluster at a depth of about $11.5 \mathrm{~km}$. The location and depth of the earthquake epicenters are consistent with the intersection of the main fault and the subsidiary fault at depth, assuming the faults are planar. The new seismic survey provides information on the structure of the fault system down to approximately $8 \mathrm{~km}$. Below that depth the main fault may continue at a similar dip, become listric or form the lower part of a flower structure. Current microearthquakes tend to favor the former two.

Acknowledgements. The field work has been supported by the Kempe Foundations (grant JCK-1202), the Swedish Nuclear Fuel and Waste Management Company (SKB; order no. 11149), LKAB (lodging, explosives and blast manager) and Uppsala University. We gratefully acknowledge the support of R. Munier (SKB), C. Dahner, P. Söderman, L. Krekula and L. Kemi (LKAB). O. Ahmadi would like to thank the University of Kurdistan and Ministry of Science, Research and Technology of Iran for their support and funding to study abroad. We also thank the field staff for their devoted work, A. Larsson, E. Nilsson, E. Bjänndal, J. Sandberg, R. Klapp, S. Lindfors, T. Rasmussen from Luleå University of 
Technology, and F. Zhang and I. Lydersen from Uppsala University. Special thanks are given to H. Palm (HasSeis), without whom this study would not have been possible. GLOBE Claritas ${ }^{\mathrm{TM}}$ under license from the Institute of Geological and Nuclear Sciences Limited, Lower Hutt, New Zealand, was used to process the seismic data. The seismic plots were generated using GMT. Quantum GIS was used to produce the maps. The authors would like to acknowledge Juan Alcalde and one anonymous reviewer for their constructive comments. Hemin Koyi is sincerely thanked for his valuable discussion on the interpretation of the seismic data.

Edited by: H. Thybo

\section{References}

Arvidsson, R.: Fennoscandian Earthquakes: Whole Crustal Rupturing Related to Postglacial Rebound, Science, 274, 744-746, doi:10.1126/science.274.5288.744, 1996.

Bäckstrom, A., Viola, G., Rantakokko, N., Jonsson, E., and Ask, M.: Preliminary results from fault-slip analysis of the Pärvie neotectonic postglacial fault zone, northern Sweden, Geophysical Research Abstracts, Vol. 15, EGU2013-1751, 2013.

Bödvarsson, R. and Lund, B.: The SIL Seismological data Acquisition System -as Operated in Iceland and in Sweden, in Methods and Applications of Signal Processing in Seismic Network Operations, eds. Takanami, T. and Kitagawa, G., Lecture Notes in Earth Sciences, 98, Springer, Berlin, 131-148, 2003.

Bungum, H. and Lindholm, C.: Seismo- and neotectonics in Finnmark, Kola and the southern Barents Sea, part 2: Seismological analysis and seismotectonics, Tectonophysics, 270, 15-28, doi:10.1016/S0040-1951(96)00139-4, 1997.

Edfelt, Å., Sandrin, A., Evins, P., Jeffries, T., Storey, C., Elming, S.- $\AA$, and Martinsson, O.: Stratigraphy and tectonic setting of the host rocks to the Tjårrojåkka Fe-oxide $\mathrm{Cu}-\mathrm{Au}$ deposits, Kiruna area, northern Sweden, GFF, 128, 221-232, doi:10.1080/11035890601283221, 2006.

Gregersen, S.: Crustal stress regime in Fennoscandia from focal mechanisms, J. Geophys. Res., 97, 11821-11827, doi:10.1029/91JB02011, 1992.

Haney, M., Snieder, R., Ampuero, J.-P. and Hofmann, R.: Spectral element modelling of fault-plane reflections arising from fluid pressure distributions, Geophys. J. Int., 170, 933-951, doi:10.1111/j.1365-246X.2007.03437.x, 2007.

Haugen, G. U. and Schoenberg, M. A.: The echo of a fault or fracture, Geophysics, 65, 176-189, doi:10.1190/1.1444708, 2000.

Heidbach, O., Tingay, M., Barth, A., Reinecker, J., Kurfeß, D., and Müller, B.: The World Stress Map database release 2008, doi:10.1594/GFZ.WSM.Rel2008, 2008.

Jones, T. and Nur, A.: Seismic velocity and anisotropy in mylonites and the reflectivity of deep crustal fault zones, Geology, 10, 260 263, doi:10.1130/0091-7613(1982)10<260:SVAAIM>2.0.CO;2, 1982.

Juhlin, C. and Lund, B.: Reflection seismic studies over the endglacial Burträsk fault, Skellefteå, Sweden, Solid Earth, 2, 9-16, doi:10.5194/se-2-9-2011, 2011.

Juhlin C., Elming S.-Å., Mellqvist C., Öhlander B., Weihed P., and Wikström A.: 2002, Onshore crustal reflectivity of the Archaean-
Proterozoic boundary and comparison with BABEL Lines 2 and 3, northern Sweden, Geophysical J. Int., 150, 180-197, 2002.

Juhlin, C., Dehghannejad, M., Lund, B., Malehmir, A., and Pratt, G.: Reflection seismic imaging of the end-glacial Pärvie Fault system, northern Sweden, J. Appl. Geophys., 70, 307-316, doi:10.1016/j.jappgeo.2009.06.004, 2010.

Juhojuntti, N. and Juhlin, C.: Seismic lower crustal reflectivity and signal penetration in the Siljan Ring area, central Sweden, Tectonophysics, 288, 17-30, 1998.

Juhojuntti, N., Juhlin, C. and Dyrelius, D.: Crustal reflectivity underneath the Central Scandinavian Caledonides, Tectonophysics, 334, 191-210, doi:10.1016/S0040-1951(00)00292-4, 2001.

Kuivamäki, A., Vuorela, P., and Paananen, M.: Indications of postglacial and recent bedrock movements in Finland and Russian Karelia (Tech. Rep. No. YST-99). Helsinki, Finland: Geological Survey of Finland, 1998.

Kukkonen, I. T., Olesen, O., Ask, M. V. S. and the PFDP WORKING GROUP: Postglacial Faults in Fennoscandia: Targets for scientific drilling, GFF, 132, 71-81, doi:10.1080/11035891003692934, 2010.

Kukkonen, I. T., Ask, M. V. S., and Olesen, O.: Postglacial Fault Drilling in Northern Europe: Workshop in Skokloster, Sweden, Sci. Dril., 11, 56-59, doi:10.5194/sd-11-56-2011, 2011.

Lagerbäck, R.: Neotectonic structures in northern Sweden, Geologiska Föreningen i Stockholm Förhandlingar, 100, 263-269, doi:10.1080/11035897809452533, 1978.

Lagerbäck, R. and Sundh, M.: Early Holocene Faulting and Paleoseismicity in Northern Sweden, Geological Survey of Sweden, 2008.

Lindblom, E. and Lund, B.: Focal mechanisms and the state of stress along the Pärvie end-glacial fault, northern Sweden, in: Microearthquake study of end-glacial faults in northern Sweden, edited by: Lindblom, E., Licentiate theses, Uppsala University, Uppsala, Sweden, 2011.

Lindblom, E., Lund, B., Tryggvason, A., Uski, M., Bödvarsson, R., Juhlin, C. and Roberts, R.: Microearthquakes illuminate the deep structure of the endglacial Pärvie fault, northern Sweden, Geophys. J. Int., 201, 1704-1716, doi:10.1093/gji/ggv112, 2015.

Lund, B. and Zoback, M. D.: Orientation and magnitude of in situ stress to $6.5 \mathrm{~km}$ depth in the Baltic Shield, Int. J. Rock. Mech. Min., 36, 169-190, doi:10.1016/S0148-9062(98)00183-1, 1999.

Lund, B., P. Schmidt, and C. Hieronymus: Stress evolution and fault stability during the Weichselian glacial cycle, TR-0915, Swedish Nuclear Fuel and Waste Management Co. (SKB), Stockholm, Sweden, 106 pp, 2009.

Malehmir, A., Schmelzbach, C., Bongajum, E., Bellefleur, G., Juhlin, C., and Tryggvason, A.: 3-D constraints on a possible deep $>2.5 \mathrm{~km}$ massive sulphide mineralization from $2 \mathrm{D}$ crooked-line seismic reflection data in the Kristineberg mining area, northern Sweden, Tectonophysics, 479, 223-240, 2009.

Mantovani, M. and Scherneck, H.-G.: DInSAR investigation in the Pärvie endglacial fault region, Lapland, Sweden, Int. J. Remote Sens., 34, 8491-8502, 2013.

Mikko, H., Smith, C.A, Lund, B., Ask, M., and Munier, R.: LiDARderived inventory of post-glacial fault scarps in Sweden, GFF, doi:10.1080/11035897.2015.1036360, 2015.

Muir-Wood, R.: The scandinavian earthquakes of 22 December 1759 and 31 August 1819, Disasters, 12, 223-236, doi:10.1111/j.1467-7717.1988.tb00672.x, 1988. 
Olesen, O., Blikra, L., Braathen, A., Dehls, J., Olsen, L., Rise, L., Roberts, D., Riis, F., Faleide, J., and Anda, E.: Neotectonic deformation in Norway and its implications: a review, Norw. J. Geol., 84, 3-34, 2004.

Pascal, C., Stewart, I. S., and Vermeersen, B. L. A.: Neotectonics, seismicity and stress in glaciated regions, J. Geol. Soc. London, 167, 361-362, doi:10.1144/0016-76492009-170, 2010.

Riad, L.: The Pärvie fault, Northern Sweden, Uppsala University, Mineralogy Department of Mineralogy and Petrology, UUDMP Research report 63, 71 pp, 1990.
Sausse, J., Dezayes, C., Dorbath, L., Genter, A., and Place, J.: 3-D model of fracture zones at Soultz-sous-Forêts based on geological data, image logs, induced microseismicity and vertical seismic profiles, C. R. Geosci., 342, 531-545, doi:10.1016/j.crte.2010.01.011, 2010.

Slunga, R. S.: The Baltic Shield earthquakes, Tectonophysics, 189, 323-331, doi:10.1016/0040-1951(91)90505-M, 1991.

Vogel, H., Wagner, B., and Rosén, P.: Lake Floor Morphology and Sediment Architecture of Lake Torneträsk, Northern Sweden, Geografiska Annaler: Series A, Phys. Geogr., 95, 159-170, doi:10.1111/geoa.12006, 2013. 